\title{
RESPONSE OF GARLIC TO NITROGEN AND PHOSPHORUS IN THE COMMON FORM AND NANO
}

\author{
Nessma, M. Anwar 1; Abou El Salehein ${ }^{1^{*}}$ E. H. ; M. M. El Hamady 1 and \\ Manal, A. Mandour 2 \\ 1. Plant Production Department, Faculty of Technological \& Development, \\ Zagazig University, Egypt \\ 2. Horticulture Research Station , Al Kassaseen - Agricultural Research \\ Center, Egypt \\ *e.mail: eelsalehein@yahoo.co.uk
}

\section{ABSTRACT}

Two field experiments were conducted during the winter seasons of 2017/2018 and 2018/2019 at a Private farm in San El. Haggar, Shrkia governorate, Egypt to evaluate the effect of potassium and phosphorus fertilizer and the formula of nano fertilizer with potassium and phosphorus on plant growth characters, chemical composition, productivity and storability of garlic cv. Chinase.

The experimental design used in the two growing seasons was randomized completes blocks with three replications.

This experiment was included 7 treatments, which were: control, $P$ fertilizer ( $\mathrm{P}_{2} \mathrm{O}_{5}$ at $90 \mathrm{~kg} / \mathrm{fedd}$, calcium superphosphate ), $\mathrm{K}$ fertilizer $\left(\mathrm{K}_{2} \mathrm{O}\right.$ at $100 \mathrm{~kg} / f e d d$, potassium sulphate ), $\mathrm{P}_{2} \mathrm{O}_{5}$ and $\mathrm{K}_{2} \mathrm{O}$ fertilizer ( $100+90$ ), Nano P ( $5 \mathrm{ml} / \mathrm{l} \quad$ ), Nano $K(5 \mathrm{ml} / \mathrm{l})$, and nano $P+K(2.5+2.5 \mathrm{ml} / \mathrm{l})$

The obtained results can be summarized as follows:

The treatment of nano potassium + nano phosphorus, followed by the treatment of potassium + phosphorus had a significant effect and recorded the highest values of plant height, fresh and dry weight of whole plant in both growing seasons. While the lowest values of vegetative growth of garlic plants were recorded by the control treatment.

There are a significant effect of the treatment of potassium + phosphorus fertilizer application caused a maximum values of average bulb weight, bulb diameter, number of cloves/ bulb and total yield / feddan. This treatment followed by the treatment of foliar application with nano potassium + nano phosphorus compared to the other treatments and control.

The treatment of the combined effect between nano potassium and nano phosphorus caused a highest values and significant effect on the 
macro. nutrients, i.e $N, P$ and $K$ of garlic leaves and nutritive values of garlic bulb compared to the other treatments and control.

The total weight loss of garlic bulbs stored were reduced gradually by the treatment of potassium + phosphorus fertilizer followed by the treatment of nano potassium + nano phosphorus and recorded the lowest values in weight loss compared the control and other treatments.

Conclusively, From these results, it can concluded that nano fertilizer can be compensate the high amounts of mineral fertilizer application which causes environmental pollution.

Key words: Garlic, phosphorus \& potassium fertilizer, nano phosphorus and potassium.

\section{INTRODUCTION}

Garlic ( Allium sativum L) is the foremost alliaceous vegetable plant, and one of main vegetable crops in Egypt for local consumption and foreign exporting market it has been used for flavoring, soup, sausages and salads, and to its medical value.

Garlic's volatile oil has many sulphur containing compounds that are responsible for the strong odor, its distinctive flavor and pungency, as well as for its healthful benefits (Salomin, 2002). In addition, it contains considerable amounts of minerals like $\mathrm{Ca}, \mathrm{P}$, and $\mathrm{K}$.

Leaves are sources of protein, vitamin A, B and c (Maly et al., 1998). Moreover, it contains antibiotics garlicin and allistatin, a number of enzymes, amino acids.

Garlic has a wide area of adaptation and cultivation throughout the world. On global scale, leading producers are china, India , Korea, Egypt, Thailand and Spain.

China and India, being the largest producers, collectively accounting for $78 \%$ of the production, but in Africa accounting only $2.8 \%$ of the world production. world area coverage by garlic was increased from 1.142,220 ha in 2003 to 1.422, 408 ha in 2011 and 1.612,713 ha in 2018 with an average productivity of 12, 16.71 and $18.17 \mathrm{t} \mathrm{ha}^{-1}$, respectively (FAO, 2003, FAOSTAT, 2011 and FAOSTAT, 2018).

The garlic bulb yield could be enhanced by improving the agriculture treatments, i.e. following the better application rate of $\mathrm{P}$ and $\mathrm{K}$ fertilizers, and / or the new.

Technology with using nano-phoshorus and nano potassium fertilizers. Phosphorus is an important nutritional element plays its part in regulating many 
physiological processes in the plant which in turn affected the resulted in total yield and quality.

As well as, potassium plays an important role on promotion of enzymes activity and enhanced the translocation of assimilates.

Moreover, it increases the root growth improve drought resistance, build cellulose, reduce loading and control plant turgidity (Edmond et al., 1981).

Many investigators concluded that $\mathrm{P}$ and $\mathrm{K}$ fertilizers increased growth, chemical composition, yield and its components, as well as bulb quality of garlic (Singh and Singh, 2006, Sud et al., 2007, El. Shal et al., 2011, Diriba Shiferaw, 2016 and Jitarwal et al., 2018).

Nanotechnology is an emerging multidisciplinary technique that involves application based on the synthesis of molecules in nano-scale size range. Nanotechnology is also seen as new and fast emerging field that involves the manufacture, processing and application of structure, device and system by controlling shape and size (Parveen et al., 2016) in nanometer scale to some of investigators illustrated that nano fertilizer increased the growth and yield of vegetables (Handy et al., 2008, Zenu et al ., 2011 and Khan et al, 2019).

Thus, this study was planned to evaluate the effect of phosphorus and potassium fertilizer either the common application or with nano phosphorus and nano potassium on growth, chemical composition, bulb yield and quality, as well as storability of garlic.

\section{MATERIALS AND METHODS:}

Two field experiments were carried out at a private Farm in San El. Hagar district , Sharkia Governorate, Egypt, during the successive seasons of 2017/2018 and 2018/2019 to study the effects of P, K fertilizer as soil application, as well as nano phosphorus and nano potassium as foliar application on plant growth parameters, chemical constituents, yield and quality, and storability of garlic plant. The soil of the experimental field was clay loam in texture with E.C. (Electric conductivity) $0.66 \mathrm{mmhos} / \mathrm{cm}, \mathrm{pH} 7.6$, available $\mathrm{N}$ was $27.8 \mathrm{ppm}, \mathrm{p} 12.9 \mathrm{ppm}$ and exchangeable $\mathrm{k}$ was $117 \mathrm{ppm}$.

The experimental design used in the two growing seasons was randomized completes block with three replications.

This experiment was included 7 treatments, which were: control, $\mathrm{P}$ fertilizer $\left(\mathrm{P}_{2} \mathrm{O}_{5}\right.$ at $90 \mathrm{~kg} / \mathrm{fedd}$, calcium superphosphate $), \mathrm{K}$ fertilizer $\left(\mathrm{K}_{2} \mathrm{O}\right.$ at $100 \mathrm{~kg} /$ fedd , potassium sulphate ), $\mathrm{P}_{2} \mathrm{O}_{5}$ and $\mathrm{K}_{2} \mathrm{O}$ fertilizer ( 100+90), Nano $\mathrm{P}$ ( $5 \mathrm{ml} / \mathrm{l})$, Nano $\mathrm{K}(5 \mathrm{ml} / \mathrm{l})$, and nano $\mathrm{P}+\mathrm{K}(2.5+2.5 \mathrm{ml} / \mathrm{l})$. 
Hyper Feed Solocross $(10-8-36)$, nano fertilizer product contains fertilizer elements with nanotechnology. Fertlizer product with high potassium supported by major and micro elements ( source of nano potassium). Hyper Feed Drip $(6-40-12)$, nano fertilizer , product contains fertilizer elements with nanotechnology. Fertlizer product with high phosphorus supported by major and micro elements ( source of nano phosphorus).

The source of nano fertilizers was Bio Nano Tech. for Fertilizers Development, El Shekh Zayed, 6 October, Egypt.

All plots of the experiment were received nitrogen as ammonium sulphate $(20.6 \%)$ at $200 \mathrm{~kg} / \mathrm{fed}$ at two equal quantities at 60 and 75 days of plant old. Phosphorus as calcium super phosphate $\left(16.5 \% \quad \mathrm{P}_{2} \mathrm{O}_{5}\right)$, potassium as potassium sulphate $\left(48 \% \mathrm{~K}_{2} \mathrm{O}\right)$, were added at two equal portions at 60 and 75 days of plant old, as well as, nano phosphorus and nano potassium as foliar application at the same times of $\mathrm{N}$ and $\mathrm{P}$ applications. Each experimental plot area was $9.6 \mathrm{~m}^{2}$ consisted of threes ridges which each ridge was $0.8 \mathrm{~m}$ in width and $4 \mathrm{~m}$ in length.

The chines cv. of garlic cloves was planted on the $11^{\text {th }}$ and $13^{\text {th }}$ October in both growing seasons of 2017/2018 and 2018/2019, respectively. The cloves were sown $10 \mathrm{~cm}$ distances on two sides of ridge.

The normal cultural treatments of growing and irrigation of garlic plant were followed as the recommended and occupied sowing by the Ministry of Egyptians Agriculture, Egypt

\section{Data recorded:}

Vegetative growth parameters:

A random sample of five plants were chosen from each plot at 90 days after planting in both seasons for measuring the vegetative growth parameters expressed as plant height, number of leaves, leaves fresh weight and leaves dry weight and whole plant.

\section{Yield and its components}

At harvest time, all the plants of each treatment were harvested and the total yield per feddan as tons was calculated after curing period for 15 days.

As well as, sample of ten bulbs was randomly taken from each treatment to determine the bulb weight, bulb diameter and number of cloves per bulb.

\section{Chemical constituents:}

The chemical constituents of garlic plants as nitrogen, phosphorus and potassium in dry weight of leaves and bulbs were determined following the described method by A. O.A.C.(2012). 


\section{Storability:}

After curing period, on random samples of $10 \mathrm{~kg}$ each were taken from each treatment, stored at the normal room conditions. The percentage of total weight loss was calculated and recorded at the storage period ( 9 months).

\section{Statistical analysis:}

All obtained data values from this study were subjected according to the analysis of variance by Snedecor and Cochran (1980) and separating the means of treatments using SAS program (SAS institute, 2004).

\section{REUSTS AND DISCUSSION}

\section{Vegetative growth characters:}

Data illustrated in Tables (1 and 2) show that the treatment of nano phosphorus + nano potassium, followed by the treatment of phosphorus + potassium had a significant effect and recorded the highest values of plant height, fresh and dry weight of whole plant in both growing seasons. While, the lowest values of the abovementioned characters were recorded from the contyrol treatment (without any addition).

The superiority of plant growth characters expressed in plant height, number of leaves, fresh and dry weight of bulb and leaves of garlic plants due to adding or foliar spraying with phosphorus and potassium in common fertilizer or in the form of nano fertilizer might be attributed to the role of phosphorus and potassium as follows: El-Shafie and El-Gomaily (2002) mentioned that phosphorus plays a vital role in metabolic processes and is a main constituent of energy compounds like nucleic acids, phospholipids and co-enzymes. Moreover, it may be attributed to favorable effects of phosphorus on root development and formation of carbohydrate and thus increased the plant vegetative growth.

Jitarwal et al. (2018) added and demonstrated that phosphorus acts as a structural component of membrane system of cells, chloroplasts and mitochondria. It is a constituent of energy phosphate like ADP and ATP, nucleic acid, nucleic proteins, purines pyrimidine, nucleotides and several coenzymes. It involved in the basic reaction of photosynthesis and plays an important role in cell division, break down of carbohydrate, transfer of inherited characteristics and increasing the maturity of plants, consequently, from these reasons, it increased plant growth.

Respecting the role of potassium on plant growth, Humber (1985) stated that potassium plays a vital role in photosynthesis which led to increase plant growth. Moreover, Marshner (1995) and Mengle (2001) illustrated that 
potassium element had a vital roles in metabolism and many processes needed to sustain and promote vegetative growth and development of garlic plant. They added that potassium plays and important roles in many physiological and biochemical processes like cell division and elongation and metabolism of protein and carbohydrate compounds besides of its role in root proliferation, leaves growth and in translocation of photosynthesis compounds to sink of physiological activity.

Metabolism and many process needed to certain and promote vegetative growth and development of garlic plant. They added that potassium plays and important role in many physiological and chemical processes like cell division and elongation and metabolism of protein and carbohydrate compounds besides of its role in root proliferation, leaves growth and in translocation of photosynthesis compound to sink of physiological activity. These results are in a good accordance with those obtained by Singh and Singh (2006), Bhandari et al. (2012) and Jitarwal et al., (2018). They showed that vegetative growth parameters of garlic plants were significantly increased with the application of phosphorus fertilizer.

In addition, Abed el. Al et al. (2005), Shafeek et al., (2013), Behairy et al.,(2015) and Arisha et al., (2017) concluded that vegetative growth characters of garlic plant significantly increased with application of potassium fertilizer.

\section{Bulb yield and its components:}

It is evident from data in Table (3) that foliar application with nano potassium + nano phosphorus resulted in a significant increase in average bulb weight and total yield of bulbs / feddan in both growing seasons, where the higher total yield was obtained from plants received both of nano fertilizers, i.e. potassium and phosphorus, followed by application of the treatment of potassium and phosphorus fertilizer compared to the control treatment (unfertilized plants. In addition, foliar spray with nano potassium and nano phosphorus reflected a significant effect on bulb diameter and number of cloves / bulb in both growing seasons, followed by the treatment of application with potassium and phosphorus fertilizer.

The lowest values of yield and its component were recorded as a result of the control treatment in both growing seasons of this study.

The maximum production of garlic bulb yield by nano potassium + nano phosphorus or potassium + phosphorus fertilizers might be attributed to encourage the formation of vigorous vegetative growth (Table 3) and good root system, which in turn absorb large amount of nutrients from soil, and activated the photosynthesis of plants and enhancing translocate of the 
produced assimilate to bulbs and then increased the weight of bulb and bulb yield. Regarding the important role of potassium and phosphorus on bulb yield, El. Shal et al. (2011) demonstrated that phosphorus is an important nutritional element plays its part in regulating many physiological crania's in the plant which in turn affect the resulted total yield. As well as, potassium plays and important and a vital role on promotion of enzymes activity and enhanced the translocation of assimilates and increased root growth and bulb yield. Similar findings were obtained by Singh and Singh (2006), Sad et al., (2007), Diriba -Shiferaw (2016) and Jitarwal et al. (2018). They studied and worked with potassium and phosphorus fertilizers as a soil application, and concluded that fertilized plants with $\mathrm{K}$ and $\mathrm{P}$ increased the yield and its components.

Moreover, Baruah (2009), Resende and Costa (2009), Derosa et al. (2010), Ekinci et al, (2014), and Khan et al (2019), who working with nano fertilizers, and they illustrated that nano fertilizer increased the yield of plants.

\section{Chemical constituents of leaves and bulb of garlic plants:}

The obtained results in Table (4) illustrate that foliar spray of potassium + phosphorus as the form of nano fertilizer and potassium + phosphorus were added to the soil had a significant effect on $\mathrm{N}, \mathrm{P}$ and $\mathrm{K}$ contents of leaves and bulb of garlic plants, compared to control plants.

Table (4): Effect of $\mathrm{K}$ and $\mathrm{P}$ in the form of normal and Nano fertilization on N, P and K contents during 2018 and 2019 seasons.

\begin{tabular}{|l|c|c|c|c|c|c|}
\hline \multirow{2}{*}{ Treatments } & \multicolumn{3}{|c|}{ First season } & \multicolumn{3}{c|}{ Second season } \\
\cline { 2 - 7 } & N\% & P\% & K\% & N\% & P\% & K\% \\
\hline Control & 0.49 & 0.11 & 0.72 & 1.75 & 0.365 & 2.13 \\
\hline K Fertilizer & 0.72 & 0.13 & 0.73 & 2.24 & 0.417 & 2.57 \\
\hline P Fertilizer & 0.77 & 0.14 & 0.84 & 2.42 & 0.462 & 2.68 \\
\hline $\begin{array}{l}\text { K + P } \\
\text { Fertilizer }\end{array}$ & 0.82 & 0.16 & 0.85 & 2.53 & 0.501 & 3.09 \\
\hline Nano K & 0.65 & 0.12 & 0.75 & 1.98 & 0.371 & 2.27 \\
\hline Nano P & 0.69 & 0.12 & 0.77 & 2.14 & 0.395 & 2.35 \\
\hline Nano K+P & 0.83 & 0.17 & 0.87 & 2.67 & 0.521 & 3.37 \\
\hline L.S.D 0.05 & $\mathbf{0 . 0 3}$ & $\mathbf{N S}$ & $\mathbf{0 . 0 1}$ & $\mathbf{0 . 0 8}$ & $\mathbf{0 . 0 4 9}$ & $\mathbf{0 . 0 9}$ \\
\hline
\end{tabular}


The simulative effect of potassium and phosphorus foliar application or soil application could be due to the rapid absorption of these nutrients from root zone which in turn increased its content in different plant parts and then increased in leaves and bulbs. Obtained results are in a good line with those obtained by Ahmed et al. (2009) Gowda et al . (2007), Bubatunde et al. (2009), El. Shal et al. (2011), Arisha et al. (2017) and Frangasmy et al.(2018), who working with fertilizers as soil application, and Ekinci et al. (2012 and 2014) who working with fertilizers as foliar spraying with nano fertilizer. They stated that fertilizer of $\mathrm{P}$ and $\mathrm{K}$ increased the contents of $\mathrm{N}, \mathrm{P}$ and $\mathrm{K}$ in leaves and storage parts of plants.

\section{Storability:}

Data in Tables (5-9) show the effect of potassium and phosphorus fertilizer, nano potassium and nano phosphorus and their combined effect on storability of garlic bulbs. Such data reveal that the total weight loss percentage of bulbs, at the end of storage period (6months) were significantly affected in both growing seasons. Moreover, the total weight loss of garlic bulbs stored were reduced gradually by the treatment of potassium + phosphorus fertilizer, followed by nano potassium + nano phosphorus.

These results are true in both growing seasons. These results may be due to the great role of $\mathrm{K}$ in carbohydrate metabolism and improving membrane structure. In addition, phosphorus plays an important role in improving the storability and longest the shelf life of bulb and decrease the bulb weight loss that may be due to it's a vital role in building the energy compounds and translocation the carbohydrate to bub stored (Ahmed et al., 2009; El. Sayed and El -Morsy, 2012), who working with potassium fertilizer, and Abo-Sedera and Badr (1998) and Mansour (2006) who working with phosphorus fertilizer on garlic plants. The obtained results are in line with those reported by Abdel Fattah et al., (2002), El- Morsy et al. (2004), and Mansour (2006).

\section{Conclusion:}

From the results of this study, it could be concluded that, under such condition soil fertilization with potassium and phosphorus fertilizer, followed by nano potassium and nano phosphorus, being the superior treatments for producing the maximum plant growth parameter, chemical constituents, garlic yield with the best storability and quality 


\section{REFERENCES}

Abd El-Al, Faten S., M.R. Shafeek, A.A. Ahmed and A.M. Shaheen, (2005). Respond of growth and yield of onion plants to potassium fertilizer and humic acid. J. Agric. Sci., Mansoura Univ., 30 (1): 441452.

Abdel Fatlah AE, Afaf Kasim and TM, El Shal (2002). Effect of some sources and levls of potassium fertilizer on growth, yield and bulb quality of garlic (Allium sativum L.) Annals of Garlic. Sci. Moshtohor, 40 (3): 1727-1738.

Abo-Sedera, F.A and L.A.A. Badr (1998). Plant growth and chemical composition of garlic plant as affected by irrigation frequency and NPK fertilization. Annals of Agric. SC. Moshtohor. 36 (2): 1057-1071.

Ahmed, M.E.M., A. Derbala and N. Abd Elkader (2009). Effect of irrigation frequency and potassium source on the productivity, quality and storability of garlic. Misr J. Ag. Eng., 26 (3): 1245-1262.

A. O. A. C.. ( 2012). Official Methods of Analysis. Association of Official and Analytical Chemists, $17^{\text {th }}$ ed.; Gaithersburg, Md, USA,

Arisha, H.M.E., K. Sabren, A. ibraheim and N.M. Elsarkassy (2017). Respond of garlic (Allium sativum L.) yield, volatile oiland nitrate content to foliar and soil application of potassium fertilizer under sandy soil conditions. Middle East Journal of Applied Science, 7 (1): 44-656.

Babatunde FE, Mofoke ALE, Udom GN, Mohammed GU (2009). Influence of nutrient source on the elemental composition of irrigated garlic. Journal of Tropical Agriculture, Food, Environment and Extension, 8:45-50.

Baruah S. and J. dutla (2009). Nantechnology application in pollution sensing and degration in agriculture; A Review Environ. Chem. Let. (3), 191-204.

Behairy, Awatef G., Asmaa R. Mohamoud, M.R. Shafeek, Aisha H. Ali and Magda M. Hafez, 2015 Growth, yield and bulb quality of onion plants (Allium cepa L.) as affected by foliar and soil application of potassium . Middle East J. Agric. Res., 4 (01): 60-66.

Bhandari S A, Patel K S and Nehete D S (2012.). Effect of integrated nutrient management on growth, yield and quality of garlic (Allium sativum L.) $c v$. Gujarat Garlic-3. Asian Journal of Orticulture.,7 (1):48-51. 
Derosa M.C.; Monreal C., Schnitzer M., Walsh R, Sultan Y., 2010 nanotechnology in ferrilizers nat. nanotechnol. 5 (2): 91.

Diriba-Shrferaw, G., Nigussic- Dechassa, R., Wolds (2016). Growth, and nutrients content and uptake of garlic (Allium sativum L.) as Influenced by different types of fertilizer and soils. Science, Technology And Arts Research Journal, 2(3): 35-50.

Ekinci M., Darsun A., Yildirm E., Parlakova F., (2012). The effects of nantechnological liquid fertilizers on plant groth and yeild in tomato. G. ulusal sebze tarimi sempoz yumu, 326-329, 14-12 Eylul, Konya, 2012 (Turkish).

Ekinci, Melek, Atilla Dursun, Ertan Yildrim, Fezilet and Parlakova Ataturk (2014). Effect of nanotechnology liquid fertilizer on the plant growth and yield of cucumber. Act Scalpel Hortorum Cults, 13 (3) (135-140).

El Morsy AHA, Zs EI Shal., Sawsan MH Sarg (2004). Effect of Potassium application methods and some micronutitiets on growth yield and storability of garlic. J. Agric. Sci. Mansoura Univ., Zg (4): 2013-2023.

El-Sayad A. El. S.H. and A.H.A El-Morsy (2012). Response of productivity and storability of garlic (Allium sativum L.) to some potassium levels and foliar spary with mepquat chaoride (PIX) International Research Journal Of Agriculture And Soil Science, 2(7): 298-305.

El-Shal .Z. S. , S, E.A. Radvlan, M.F Zaki and Fatama A. Rizk (2011). The productivity of garlic plant (Alliun sativum) as affected by plant densities and NPK application. J. Agric. Sci, Mansoura University,.2 (7): 865-875.

Emonde, J.B.; T.L Senn,.; F.S. Znterw, and A.G. Hulfacre (1981). Fundamental of horticulture. Tata Mc Graw. Hill. Publishing Co., Limited, India.

FAO (2003). Food And Agriculture Organization. Optimizing Soil Moisture For Plant Production FAO Soils Bull., 79,22-23-Food and Agriculture Organization of the united nations, Rome.

FAO, 2018. Statistical Yearbook. Food and Agriculture Organization (FAO), Rome, Italy.

FAOSTAT (2011). Food and Agriculture Organization of the United Nations Satistics. (2011). htt://faostat. fao.org/site/5677 desktop defaw. Apexp page $\mathrm{ID}=567 \#$ ancor;21/12/2013. 
Frangasmy A, Yogesh Khade and Singh Major (2018). Nutrient management in onion and garlic. Journal of Allium Research, (1): 107115.

Gowda, M.C., M. Vijayakumar, and A.P.M. Gowda (2007) Influence of integed nutrienj management on groth, yield and quality of garlic. Agricultural Crop Research, 33 (1/3):144-147.

Humber, S.C.(1985). Role of potassium in photosynthesis and respiration. P.p 369-3696. In potassium in agriculture .American Society of Agronomy, Madison, Wi.

Jitarwal ,Om Prakash, MR Choudhary, Argunlal ola Ramavatar Choudhary and Ganpat lal Yadar (2018). Effect of phosphorus levels on growth, yield and quality of garlic (Allium sativum L.). Journal of Chemical Studies, 5(6) (1816-1819).

Khan, I., S. Khalid , and I. Khan (2019). Nanoparticles: Properties, applications and toxicities. Arabian Journal of Chemistry ,12(7: 908931

Maly, I. Bartos, J., H Lusek, J., Kopec, K., K Peteikova,., J.Rod, , and P.Spitz, (1998). Polnizelina. Stiv.Agrospoj Praha, 175-185.

Mansour, F.Y.O. (2006). Physiological studies on garlic (Allium sativum L.) M.SC. Thesis, Fac. Agric.; Minufiya. Univ; Egypt.

Marschner H. 1995. Mineral Nutrition of Higher Plants. 2 nd Ed. Academic Press, Harcourt Brace and Company, Publishers. London, New York, Tokyo, pp 864.

Mengel K. (2001). Principles Of Plant Nutrition 5th ed, Kluwer Academic Publishers Dordrecht." The Netherlands, pp.481-509.

Parveen, K., V. Banse, and L. Ledwani (2016).Green synthesis of nanoparticles: their advantages and disadvantages. Acta Nat.(2016), p. $20048,10.1063 / 1.4945168$

Resende GM, ND Costa (2009). Effect of levels of potassium and nitrogen on yields and harvest conservation of onions in winter. Horticultura Brasileira, 26: 388-392.

Salomin, R.(2002). Virus diseases in garlic and the propagation of virus free plannting. PP. 311-327 in rabinowthc, H.D., Currail. (EDs) Alium crop sciences: recent advances international, walling food, VK. http://dx.doi.org/10.1079197808519951606.0311.

SAS Institute (2004). SAS/STAT user's guide.Version 8.2.SAS Institute, Cary, USA. 
Shafeek, M.R., Nagwa, M.K. Hassan, S.M. Singer and Nadia H.M. ElGreadly, (2013). Effect of potassium fertilizer and foliar spraying with ethereal on plant development, yield and bulb quality of onion plants (Alluim cepa L). J. Appl. Sci. Res., 5(2): 1140-1146.

Singh, A. K. and S.P. Singh (2006). Effect of levels of nitrogen and phoshours in conjuction with karing pknt and densities on some important bulb characters and yield of garlc (Allim sativum L.). International Journal of Agricultural Sciences, 2(2): 490-492.

Snedecor, G.W., Cochran, W.G. (1980). Statistical Methods. $7^{\text {th }}$ Edition, Ames: Iowa State University Press. USA. 480p.

Sud, K.C.; Trehan, S. P.; Lal, S. S. (2007). Performance of organic and inorganic in potato - garlic sequence under zero tillage in the mid hills of Himachal Pradesh. Potato J., 34(3/4) 203-208.

Yadav, R.L., N.L. Son and B.L. Yadave, (2003). Response of onion to nitrogen and potassium feritization under

Zenu JHA, NEHA Behar, SHIV Narayan Sharma, G. Chandel, D.K Sharma and M. P.P. Pandey (2011). Nano. Vision, Vol. 1, pages (54100). semi-arid condition of Rajasthan. Indian J. Hortic., 60 (2): 176178.

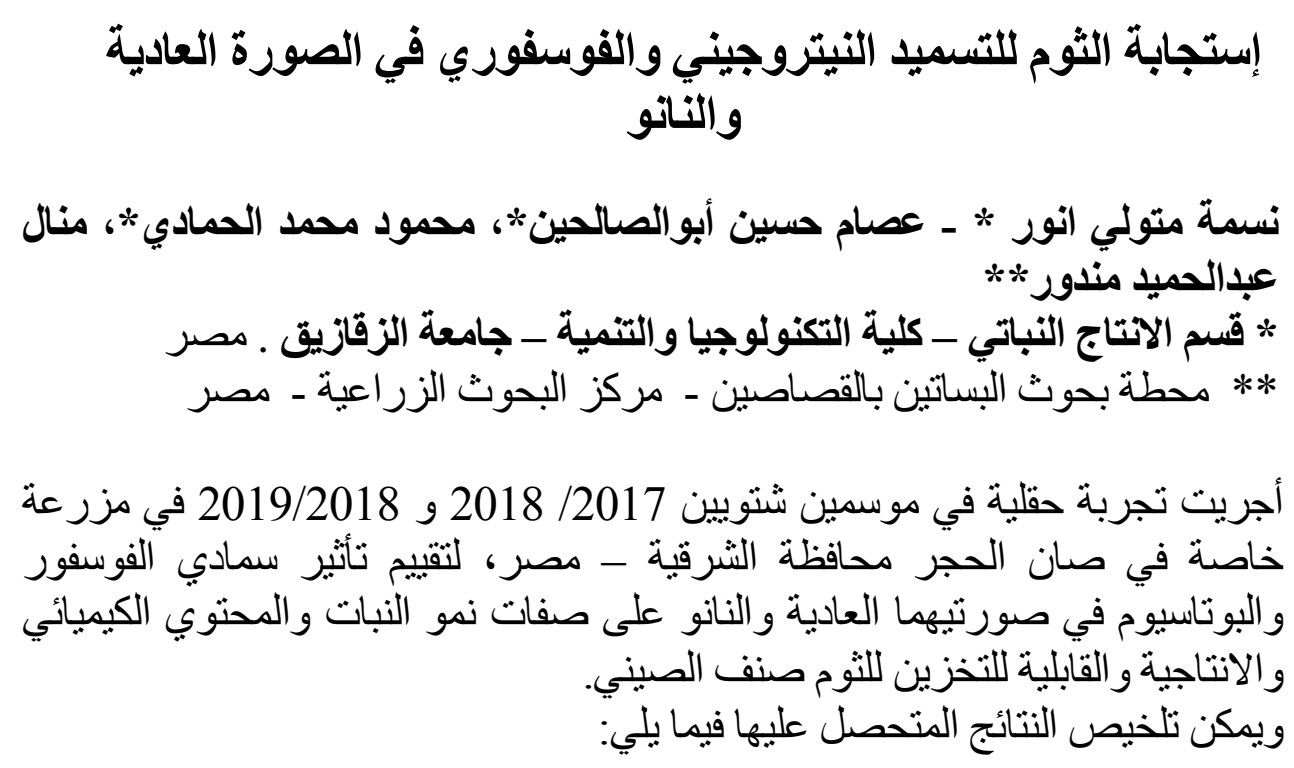


أثرت معنوياً معاملة النانو بوتاسيوم + النانو فوسفور، متبوعة بمعاملة التسميد

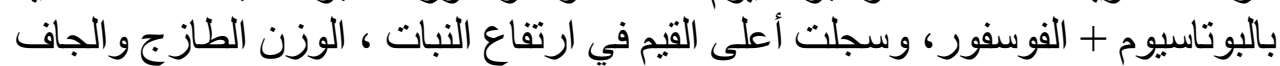

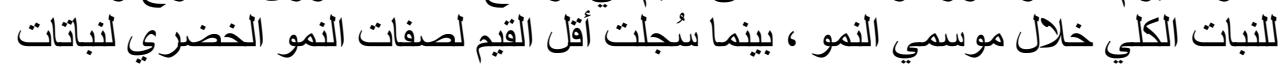
الثوم بمعاملًة المقارنة. بالنظر إلي المعاملات المدروسة على المحصول المعاد ومكوناته لنباتات الثوم وجد تأثير

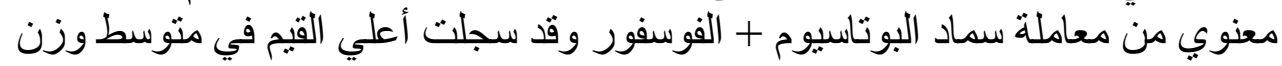

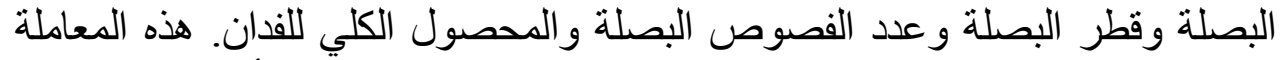

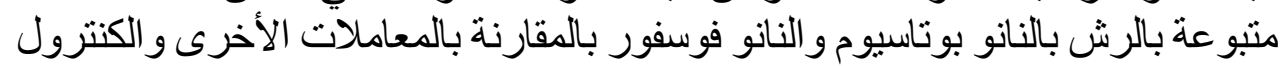

(المقارنة).

محتوي النيتروجين والفوسفور و البوتاسيوم في الأوراق وأبصال الثثوم سجلت معاملة

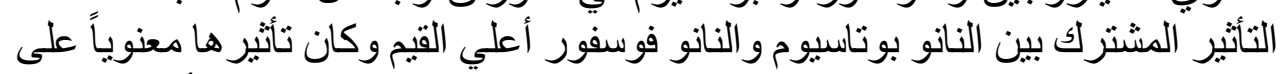

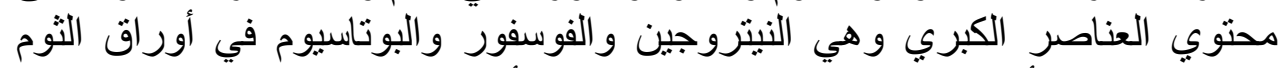

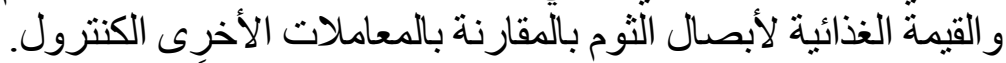

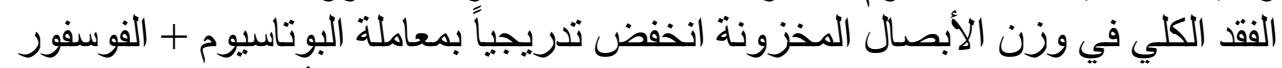

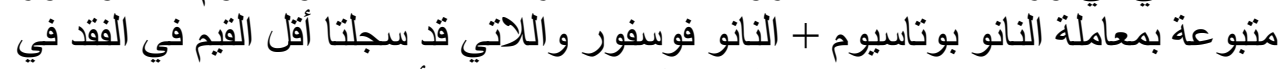

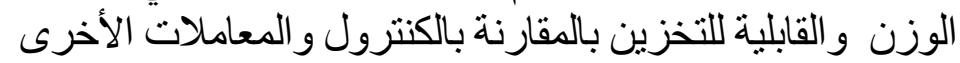

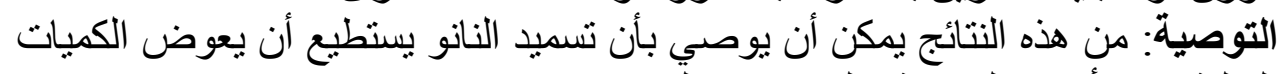

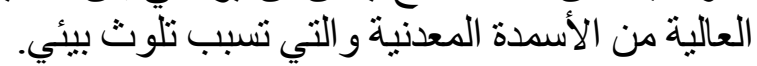

